\title{
Multivariate Analysis for the Quality of Practice of Midwifery Clinic on Student Satisfaction of Midwifery Academy Sari Mulia \\ Banjarmasin
}

Yayuk Puji Lestari ${ }^{1^{*}}$

*yp_lestari@stikessarimulia.ac.id

${ }^{1}$ School of Health Science Sari Mulia, Banjarmasin Indonesia

Anggrita Sari ${ }^{2}$,

${ }^{2}$ Academy of Midwifery Sari Mulia, Banjarmasin Indonesia

Anggrita_sari@akbidsarimulia.ac.id

R.Topan Adhitya $\mathrm{R}^{2}$,

${ }^{2}$ Academy of Midwifery Sari Mulia, Banjarmasin Indonesia

r_topan_aditya@akbidsarimulia.ac.id

\begin{abstract}
Purpose: This study aims to analyze the effect of learning quality of midwifery clinic practice on student satisfaction of Midwifery Academy Sari Mulia Banjarmasin

Method: The research method used is quantitative with cross-sectional research approach design. The population was 293 students using Propositional Random Sampling technique to get 75 samples and analyzed logistic regression test

Result: The regression test analysis resulted in the model that fix the learning quality of midwifery clinic practice to student's satisfaction with Reliability value $(\mathrm{p}=0.002)$, Assurance $(\mathrm{p}=0.002)$, Tangible $(\mathrm{p}=0,006)$

Conclusion: Dimensions Reliability, Assurance and Tangible are the most influential on student satisfaction at the midwifery academy of Sari Mulia Banjarmasin.
\end{abstract}

Keywords: Certainty, Clinical practice learning, Empathy, Responsiveness, Satisfaction

\section{INTRODUCTION}

Education plays an important role in shaping the characteristics and quality of one's life. Through education, people are required to be able to behave, act and think in the living process.

Midwifery Diploma III Education is vocational education. Students are required to have $60 \%$ skills so that the learning process is more emphasized on teaching outside educational institutions such as clinical practice to realize professionalism. Students are required to have professional skills in running care at the hospital, public health center, midwives and independent practices in the community [1].

Clinical practice is part of a curriculum that can not be separated from theory. Students 
must follow direct learning with clients in the practice area. Students need the guidance of a clinical instructor to gain clinical experience for the achievement of midwifery skills. Practice is a learning strategy to improve students' cognitive, psychomotor, and effective (attitude) abilities. In addition, the clinical practice provides an opportunity for students to apply and apply the knowledge and skills that have been previously owned significantly. Educational institutions are expected to improve the quality of management to meet the target competencies that have been set [2].

In the implementation of the practice, AKBID Sari Mulia cooperates with several parties such as Hospital, Puskesmas, BKIA and BPM in Banjarmasin City Region.

Satisfaction includes the five dominant factors or the determinant of service quality, which ultimately determines the level of satisfaction, including student satisfaction in learning midwifery clinical practice. The five factors are reliability, responsiveness, certainty, empathy, and form. Quality or quality in the education service must be considered in order to produce graduates who are competent in accordance with the curriculum [3].

The result of research on Quality Relationship of Practical Learning in Midwifery Laboratory with the level of student satisfaction of AKBID Sari Mulia is obtained from 5 dimensions of quality (reliability, responsiveness, certainty, empathy, and form) only uncertainty relating to student satisfaction in learning obstetric laboratory practice [4 ].

The results of preliminary study of clinical practice and laboratory practice test values in the past 3 years were 83.3 and 77 in 2010, 79 and 76 in 2011, and 79.6 and 73 in 2012

The results of discussions conducted by 10 clinical counselors and 6 of them said that students who practice less motivated questions and less initiative in practice so that counselors find it difficult in providing direction in practical implementation.

Results of discussions with 10 education counselors and 7 of them revealed that students are currently less active in consulting practice results. They consult when the practice will end or even after the practice ends so that the counselor has difficulty crosschecking if there is a gap. Besides, it also held discussions with 10 students, 6 of them said the practice was only to fulfill the task of the campus

This illustrates that the quality of learning of midwifery clinic practice has progressed towards the decrease of average of midwifery clinical learning result so that in this case it is necessary to do research to analyze Multivariate of learning quality of midwifery clinic practice (5 dimension that is reliability, responsiveness, certainty, empathy, and form) against student satisfaction. 


\section{METHODS}

The method used is an analytical survey that uses a quantitative design with Crosssectional approach. This research is done in Midwifery Academy Sari Mulia Banjarmasin. Independent Variable is the quality of Clinical Practice of Midwifery Practice which is focused on 5 dimensions namely reliability, responsiveness, certainty, empathy and shape. The dependent variable is student satisfaction level of Midwifery Academy Sari Mulia Banjarmasin.

The population used is all students of years I and II Midwifery Academy Sari Mulia Banjarmasin FY 2013/2014 which amounted to 293 students. The number of samples taken is formulated based on the determination of the sample size of 75 students with Proportional Random Sampling technique. The proportion of each class is presented in table 1.

Table 1 Population and Research Samples

\begin{tabular}{cccc}
\hline No & Classes & $\begin{array}{c}\text { Population } \\
\text { Number }\end{array}$ & Sample Proportion \\
\hline 1 & A & 48 & 12 \\
\hline 2 & C & 44 & 12 \\
\hline 3 & D & 48 & 12 \\
\hline 4 & A & 51 & 13 \\
\hline 5 & B & 60 & 15 \\
\hline 6 & D & 42 & 11 \\
\hline
\end{tabular}

The data sources used are primary data (questionnaire) and secondary data (Practical section report in the value of midwifery clinic practice.

The data analysis is done by passing several stages: checking data, giving code, entering data and last analyze the effect of using simple logistic regression [6].

\section{RESULTS}

After bivariate analysis, all have p-value 0.25 which can be continued to multivariate analysis that is logistic regression analysis. This can be seen in the following table: (Table 2)

Based on table 2 can be seen that the results of the analysis performed simultaneously obtained reliability results with the value of $p=0.999$, Empathy with $p$-value $=1,000$, Power Response with value $\mathrm{p}=$ 1,000 , Certainty obtained p-value $=0.002$, while the form has a value $\mathrm{p}=0.008$. Further analysis is done by removing one by one dimension having the highest $\mathrm{p}$-value, it can be seen that empathy variable and responsiveness can be issued. 
Table 2 Results of Logistic Regression Analysis Effect of Quality of Clinical Practice of Midwifery on Student Satisfaction Akbid Sari Mulia Banjarmasin FY 2013/2014 In 2014

\begin{tabular}{|c|c|c|c|c|c|c|c|c|c|}
\hline \multirow{2}{*}{ No } & \multirow{2}{*}{ Variable Bebas } & \multirow{2}{*}{ B } & \multirow{2}{*}{ SE } & \multirow{2}{*}{ Wald } & \multirow{2}{*}{ Df } & \multirow{2}{*}{ Sig } & \multirow{2}{*}{$\operatorname{Exp}(B)$} & \multicolumn{2}{|c|}{ 95\% C.I.for EXP(B) } \\
\hline & & & & & & & & Lower & Oper \\
\hline 1. & Kehandalan & 39,7 & 49226,2 &, 000 & 1 & ,999 & 1850 &, 000 & \\
\hline 2. & Kepastian & 2,2 & ,7 & 9,3 & 1 & ,002 & 9,1 & 2,2 & 37,8 \\
\hline 3. & Empati & $-19,8$ & 40193,1 & ,000 & 1 & 1,000 & ,000 & ,000 & . \\
\hline 4. & Daya tanggap & $-17,6$ & 28420,6 & ,000 & 1 & 1,000 & ,000 & 000 & . \\
\hline 5. & Wujud & 3,2 & 1,2 & 7,1 & 1 & ,008 & 26,5 & 2,3 & 295,0 \\
\hline & & & $\mathrm{P}=0.05$ & & & & & & \\
\hline
\end{tabular}

Table 3 Results Logistic Regression Analysis Fit Model Quality Quality Practice Clinic Midwifery Against Student Satisfaction Akbid Sari Mulia Banjarmasin FY 2013/2014 The year 2014

\begin{tabular}{|c|c|c|c|c|c|c|c|c|c|}
\hline \multirow{2}{*}{ No } & \multirow{2}{*}{ Variabel Bebas } & \multirow{2}{*}{ B } & \multirow{2}{*}{ SE } & \multirow{2}{*}{ Wald } & \multirow{2}{*}{ Df } & \multirow{2}{*}{ Sig } & \multirow{2}{*}{$\operatorname{Exp}(B)$} & \multicolumn{2}{|c|}{ 95\% C.I.for EXP(B) } \\
\hline & & & & & & & & Lower & Th \\
\hline 1. & Kehandalan & 2,4 & ,7 & 9,6 & 1 & ,002 & 11,3 & 2,4 & 52,5 \\
\hline 2. & Kepastian & 2,2 & ,7 & 9,3 & 1 & ,002 & 9,0 & 2,2 & 37,4 \\
\hline 3. & Wujud & 3,3 & 1,2 & 7,4 & 1 & ,006 & 28,8 & 2,5 & 322,6 \\
\hline
\end{tabular}

Based on table 3, not all variables have a mutual influence on student satisfaction in learning midwifery clinic practice. Variable empathy is issued when there is no influence on other variables after that proceeded to issue the variable responsiveness turns out the variable responsiveness is very influential on the variable reliability, certainty, and form that have an influence on student satisfaction. The quality dimension of reliability has a value of $\mathrm{p}(0.002)$, the dimension of certainty has $\mathrm{p}$ value (0.002) and the quality dimension of being has p-value (0.006). Reliability has a minimum level of 2.4 to 52.5 times greater for student satisfaction, the dimension of certainty has a minimum level of 2.2 to 37.4 times greater to improve student satisfaction. Likewise, the dimension of being has a minimum level of 2.5 to 322.6 times greater to improve student satisfaction.

\section{DISCUSSION}

The influence of learning quality of midwifery clinic practice on student satisfaction can be identified from multivariate test result using Logistic Regression, and based on a summary of the Multivariate analysis result, it can be seen that not all variables have influence together to student satisfaction in learning of midwifery clinic practice. Variable empathy is issued when 
there is no influence on other variables. After that followed by releasing the variable responsiveness was the variable responsiveness is very influential on the variable reliability, certainty, and form that has an influence on student satisfaction.

To improve student's satisfaction, attitude, attention, and willingness of lecturer and manager in providing services to students should be further improved. This is in accordance with the opinion [7] which states that empathy and responsiveness are part of the quality dimension that has a close relationship with satisfaction.

One of the key success factors in improving service quality is by listening to the voice of the customer, in this case, the student, demanding the fulfillment of the need for quality [8].

This is consistent with the one done by Agel [9] that states that there is a positive and significant relationship between the competence of mentors in making learning, utilizing media learning and manage the quality of learning

A product is said to be of quality to a person if the product can meet its needs. Likewise, students feel that the quality of services provided if the services provided by lecturers and managers in accordance with the needs of students with a good attitude and attention aims to assist students in midwifery laboratory. One of the key success factors in improving service quality is by listening to the voice of the customer (Listening to the voices of Customer)

Results of research on PSIK students in Skill's Lab of UGM Faculty of Medicine in 2002 showed that students' perceptions of PSIK in general to instructors and learning process are not good. While the results of research conducted [10] said that there is a relationship between empathy perceptions and responsiveness with student satisfaction in learning laboratory practices. His research shows that respondents who have empathy perception are not good to have a tendency not satisfied, on the contrary respondent having good empathy perception tend to feel satisfied. Not much different results found in AKBID Palembang students indicating that the obstacles in the implementation of the learning process in the laboratory is the allocation of available time is not in accordance with the competence to be achieved, the lack of willingness of the laboratory manager to help students so that students encounter difficulties in carrying out laboratory practices.

\section{CONCLUSION}

Based on the research and the discussion, it can be concluded that Multivariate Analysis resulted in the dimensions of reliability, certainty and the most influential form of learning quality of clinical practice midwifery. 


\section{REFERENCES}

[1] Arikunto, Suharsimi. Prosedur Penelitian Suatu Pendekatan Praktik. Jakarta: Rineka Cipta,[8] 2010

[2] Puji, Indah. Pengaruh Mutu Pembelajaran Terhadap Hasil Belajar. Matematika. Jurnal Formatif, 2003; 3(2): 125-145; 2013

[3] Supranto. Pengukuran Tingkat Kepuasan Pelanggan Untuk Menaikkan Pangsa Pasar, Edisi Baru, Jakarta: Rineka Cipta, 2010

[3] Laurensia, Yunita. Hubungan mutu pembelajaran praktik di laboratorium dengan tingkat kepuasan mahasiswa AKBID Sari[10] Mulia, STIKES Sari Mulia, 2011

[5] Hidayat, A.Aziz Alimul. Metode Penelitian Kebidanan dan teknik Analisis Data. Jakarta : Salemba Medika, 2012

[6] Soekidjo, Metodologi Penelitian Kesehatan. Jakarta: Rikena Cipta , 2010

[7] Winarsih, Sri. Pengaruh persepsi mutu pembelajaran laboratorium kebidanan terhadap kepuasan mahasiswa di Prodi
Kebidanan Magelang tahun 2007, Tesis yang tidak dipublikasikan, Program Pasca Sarjana UNDIP Semarang, 2010

Atik, Rahayu. Pengaruh Dosen, Fasilitas, Orang Tua dan Kemandirian terhadap Kualitas Belajar Mahasiswa Politeknik Negeri Padang. Jurnal R \& B, 3 (2) ; 2013.

Angel. Pengaruh Self-Efficacy Guru dan Kreativitas Pembimbing Terhadap Pembelajaran Siswa dan Implikasinya terhadap Prestasi Belajar pada Mata Pelajaran Ekonomi. SOSI DIDAKTIKA : Social Sciense Education Journal, Vol.4. No.3 ; 2016

Pinggel. Wangid, Adel . Faktor yang Mempengaruhi Pembelajaran Praktik Klinik Tabalong. Jurnal Pendidikan Vol.2, No.1 ; 2015. 